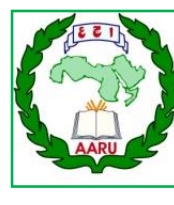

Arab Univ. J. Agric. Sci., Ain Shams Univ., Cairo, Egypt

29(2), 715-721, 2021

Website: http://ajs.journals.ekb.eg

DOI: 10.21608/ajs.2021.68600.1352

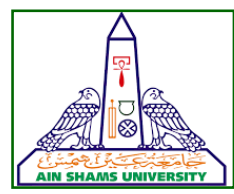

715

\title{
DNA Barcoding of Commercial Three High Value Red Sea Fishes from The Egyptian Market
}

\author{
Rana A Gamal-Eldin*, Mohamed A Rashed, Mahmoud Magdy \\ Genetics Dept, Fac of Agriculture, Ain Shams Univ, P.O. Box 68, Hadayek Shoubra \\ 11241, Cairo, Egypt \\ *Corresponding author: rna.ashraf.gamaleldin@gmail.com
}

Accepted 20 May, 2021

\begin{abstract}
Fish play an essential role in food security and are regarded as one of Egypt's primary food resources and, therefore, significantly impact the national economy. The three main sources of fish production in Egypt: marine (Red and Mediterranean seas), lakes and the River Nile, due to the elevated incidence of species substitution at the global level, precise identification of seafood species on the markets considered a solution for food safety control institutions and human consumer protection. Mislabeling occurs when one species is substituted for another. Different species of red sea marine fish were collected from the Egyptian market. According to the Arabic name in the fish market, Samples searched for English and Latin family names in (www.fishdatabase.org). Commercial samples were successfully extracted and confirmed with $1.5 \%$ agarose gel electrophoresis. The result showed that the mtDNA gene cytochrome $\mathrm{c}$ oxidase subunit I (COI) amplification was successful for all samples with high concentration, it was purified and sequenced for both directions and blasted using the NCBI database. Resulting in the identification of three commercially essential and expensive fish samples, Baghbaghan (parrotfish), Hamour (Greasy Grouper) and kahaya (Spiny squirrelfish). One of them correctly identified according to the market name,
\end{abstract}

while the other two are recorded mistakenly under another name.

Keywords: DNA barcoding, Mislabelling, COI, Egypt fish market, Marine fish, Red sea

\section{Introduction}

The Red Sea is one of the most interesting seas to study its aqua biotic diversity due to its distinctive oceanographic and biological characteristics. It is also considered an important source of consumed seafood for a long time by humans who live along its coasts. Egypt is one of the seven countries that considered the Red Sea an important fishing source, especially coral reef studies of aqua biotic diversity and a hot spot of tourism attraction. Its shoreline is crowded, creating stress on marine habitats (Tesfamichael and Pauly 2016). Fish diversity in the red sea is very high, the fishes current diversity exceeds 1,400 species recorded by Fish Base. Using morphology as a tool for species identification is hit with several limitations, including the inability to uncover hybrid and cryptic species diversity, the identification becomes difficult or even impossible when it comes to the identification of early life stages (egg and larvae), the time-consuming, and the high level of expertise needed to species identification (Strauss and Bond 1990). 
The authentication of fish and seafood species and species substitution detection has become an essential topic in the food industry. There is an increasing need for rapid, reliable, and reproducible tests to verify species in commercial fish and seafood products. Increases in international trade and global consumption of seafood, along with fluctuations in the supply and demand of different fish and seafood species, have resulted in the products mislabeled. The effects of species substitution are farreaching and include economic fraud, health hazards, and illegal trade of protected species (Galal-Khallaf et al 2014). Various DNAbased techniques have been developed to improve seafood fraud detection, including Multiplex PCR, PCR-RFLP, PCR-RAPD, PCRAFLP, and PCR-SSCP are all based on polymorphisms in the genetic codes of different species (Rasmussen and Morrissey 2008). Hebert et al (2003) proposed establishing a DNA barcoding system for all living organisms, based on the sequencing of a $650 \mathrm{bp}$ region of the mitochondrial Cytochrome Oxidase I gene (COI). For a barcoding method to define species to be successful, within a species DNA sequences need to be more similar to sequences in different species. Recent studies show that this is generally the case, the DNA barcoding identification technique has been proven effectively discriminate fish species (Ward et al 2005). The international program "Barcode of Life Initiative" has been created for studies and molecular cataloging of species diversity of all animals and plants on the planet (http://www.barcoding.si.edu/). The main aim was to provide molecular identification of organisms using a standardDNA region (DNA barcode) and to create a more taxonomically accurate species identification database. The DNA barcoding is not a substitute for taxonomy, it does provides a powerful tool to help identify species and focus futuretax onomic research efforts (Ahmed et al 2016). This study aimed to identify three expensive red sea fish species sampled from the Egyptian market based on COI sequences using NCBI-BLAST and phylogenetic analysis.

\section{Material and Methods}

Different species of red sea marine fish were collected from the Egyptian market. Samples were named according to Arabic names in the fish market and searched for English and Latin family names in www.fishbase.org (Table 1).

A piece of $1 \mathrm{~cm}^{2}$ of dorsal fins and tail from each sample was stored individually in $96 \%$ ethanol at $-20^{\circ} \mathrm{C}$ until DNA extraction. Data were recorded, including the market name, the anticipated family name, and morphological measurement. DNA was isolated from finfish, according to Younas (2016). Initially, 50mg of fin tissue of each fish species were cut into small pieces with sterilized scissors and dried on filter paper. Fin tissues were incubated in $15 \mathrm{ml}$ tube containing $1.94 \mathrm{ml}$ lysis buffer $(200$ $\mathrm{mM}$ Tris- $\mathrm{HCl} \mathrm{pH} 8.0,100 \mathrm{mM}$ EDTA, 250 $\mathrm{mM} \mathrm{NaCl}, 10 \mu 1$ Proteinase $\mathrm{K}(20 \mathrm{mg} / \mathrm{ml})$ and $60 \mu 1$ of $20 \%$ SDS. The tube's contents were incubated at $48^{\circ} \mathrm{C}$ for $2-3 \mathrm{~h}$ in a water bath. The DNA was isolated by adding $2 \mathrm{ml}$ of phenol: chloroform: isoamyl alcohol $(25: 24: 1)$ in the tubes after incubation. The tube contents were mixed manually by gentle mixing for 10 $15 \mathrm{~min}$ and then centrifuged at $13000 \mathrm{rpm}$ for $15 \mathrm{~min}$. The top aqueouslayer was removed and transferred in a new tube, leaving the interphase and lower phase. An equal volume of chloroform was added to the tube's contents, mixed by inverting the tubes, and centrifuged at $13000 \mathrm{rpm}$ for $15 \mathrm{~min}$. Again, the top transparent layer was removed, leaving the interphase and lower phase. After this, an equal volume of isopropanol and 0.2 volume of ammonium acetate $(10 \mathrm{mM})$ were added in the tube containing the aqueous phase and incubated for $30 \mathrm{~min}$ at $-20^{\circ} \mathrm{C}$ for good precipitation of DNA. The pellet of DNA was formed by centrifugation of tubes again at $12000 \mathrm{rpm}$ for 5 minutes. The DNA pellet was washed twice by cold $70 \%$ ethanol, dried, and dissolved in the appropriate injection water volume. 
DNA Barcoding of Commercial Three High Value Red Sea Fishes from The Egyptian Market

Table 1. Recorded Data including Arabic Market name addition to its English match name, Latin order, family, and genus name offered by Fishbase.org

\begin{tabular}{|c|c|c|c|}
\hline Species & S1 & S2 & S3 \\
\hline Arabic market name & Baghbaghan & Nagil & Kahaya \\
\hline English name & Parrot Fish & Nagil & soldierfish \\
\hline Proposed Order & Perciformes & Perciformes & Beryciforms \\
\hline Proposed Family & Scaridae & Serranidae & Holocentridae \\
\hline Proposed Genus & Scarus & Plectropomus & Myripristis \\
\hline
\end{tabular}

COI partial sequence was amplified using the following primers. Forward primer(FF2d 1) with sequence (5'-TTCTCCACCAACCACAARGAYAT-YGG-3') and Reverse primer (FR1d 1) with sequence (5'-CACCTCAGGGTGTCCGAARAAYCARAA-3') PCR had a total volume of $25 \mu \mathrm{L}$ and included: $1 \mu \mathrm{L}$ of Go Taq ${ }^{\circledR}$ Felxi buffer, $4 \mathrm{mM} \mathrm{MgCl} 2,1$ $\mu \mathrm{L}$ of each primer, $0.25 \mathrm{mM}$ of each dNTP, 2 $\mu \mathrm{L}$ of DNA sample, 1.25 of Go TaqTM and up to $25 \mu \mathrm{L}\left(\mathrm{dd} . \mathrm{H}_{2} \mathrm{O}\right)$ total volume. The thermocycler profile for COI- 1 consisted of $94^{\circ} \mathrm{C} / 2$ min, 35 cycles of $94^{\circ} \mathrm{C} / 30 \mathrm{~s}, 52^{\circ} \mathrm{C} / 40 \mathrm{~s}$, and $72^{\circ} \mathrm{C} / 1 \mathrm{~min}$, with a final extension at $72{ }^{\circ} \mathrm{C}$ for $10 \mathrm{~min}$. PCR products were visualized on a $2 \%$ agarose gel contains $2 \mu \mathrm{l}$ of EthBr using an Agarose Electrophoresis System.

PCR purified products have been labeled using the BigDye terminator V.3.1 Cycle Sequencing kit (Applied Biosystems, Inc.) and bidirectionally sequenced using ABI 3730 automated Sanger sequencer (Macrogene, Inc.). The sequence has been assessed, assembled, and aligned with Geneious V8.1 software and submitted to the database of GenBank. Using DNA associated database (BLASTn) refined sequence was used to identify the species.

\section{Result and Discussion}

DNA barcoding is one of the most important studies in the taxonomic, evolutionary, environmental, and phylogeographic analysis. To avoid the limitations of the traditional morphological methods of species identification, the DNA barcoding identification technique was used as it proved to be more accurate
(Hebert and Gregory 2005). Despite the importance of DNA barcoding technique but it's necessary to emphasize that DNA barcoding is not intended to define species but rather uses sequence diversity to identify groups with similar and related sequences and that can be identified as species. Ebach and Carvalho (2010) also noted that DNA barcoding could not replace the traditional molecular definition of species for species taxonomy. It remains an additional tool for companies and governments to make species identification more accurate and more manageable for non-taxonomists to use, for example, forfish market quality control and for consumer safety purposes.

In most cases, universal fish primers for the COI fish gene have been successfully amplified using the proposed extraction protocols from finfish and muscle tissue (Ivanova et al 2007). The total of the three commercial species of marine fish genetic material was successfully extracted in triplicates and confirmed using $1.5 \%$ agarose gel electro phrases, as shown in (Fig 1). The COI amplification was successful for all samples with sufficient quality and quantity for sequencing at the expected molecular weight ( $\sim 650 \mathrm{bp})$. One sample of each species was further processed for PCR purification and DNA sequencing.

The observation in the present study showed that these three red sea species under study plays an essential role in the Egyptian market, so Hamour is one of the tasty and pricey fish one that can be obtained from the red sea fish market, parrotfish is also one of the pricey fish, and Kahaya is one of the delicious fish that most restaurants use in seafood soup. 


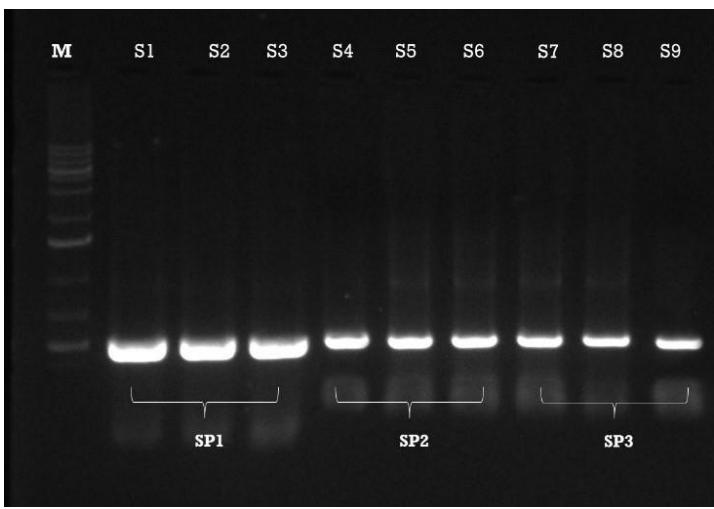

Fig 1. PCR a mplification of COI region of $\sim 650 \mathrm{bp}$ length for triplicates of the three species understudy

For species 1 (Baghbaghan), the retrieved information from the Egyptian market confirmed its local common name as Baghbaghan. Based on the Arabic common name, it was easy to retrieve its genus as Scarus and family name Scaridae. It is widely distributed in the Western Indian Ocean and Red Sea (Fig 2). Therefore, it was possible to know the expected species and recorded as the parrotfish (Scaruscollana). The DNA barcoding analysis based on NCBI-BLAST matched the proposed genus and species successfully with a similarity of 99.2\% (Table 2).

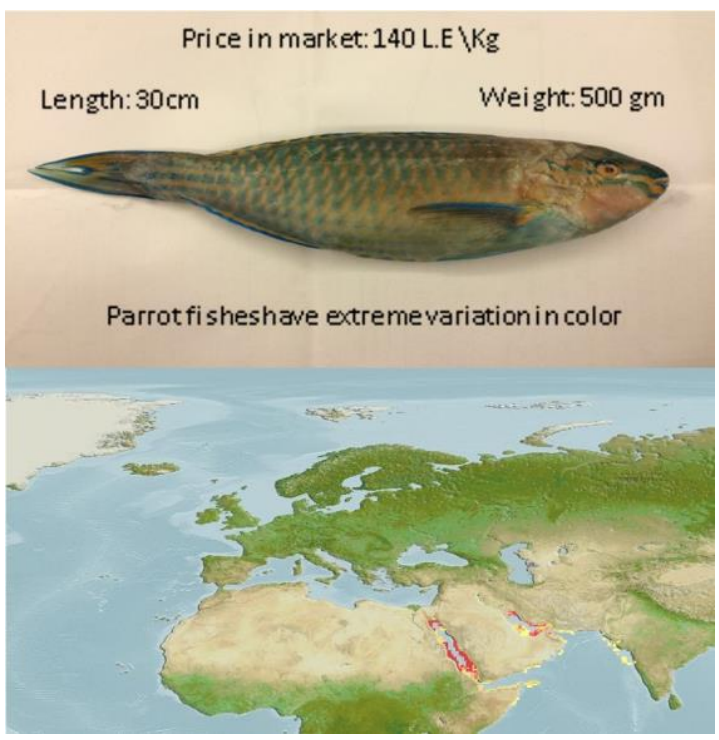

Fig 2. A photo of the Parrotfish (Baghbaghan) Scarus collana (Above). The native distribution map for Scarus collana according to www.aquamaps.org, version of Aug. 2016 (Below).
For species 2 (Nagil), the retrieved information from the Egyptian market confirmed its local common name as Nagil. This species was found similar to another grouper known as "Hamour", and proposed to belong to the genus Plectropomus and family Serranidae. It is distributed in the Indo-Pacific, The Red Sea to South Africa and eastward to Ducie in the Pitcairn Group, north to Japan, south to New South Wales and Lord Howe Island as shown in (Fig 3). The DNA barcoding analy sis based on NCBI-BLAST did not match the proposed genus and species, however, the Arabian grouper known as greasy grouper, Epinephelus tauvina successfully with matched $99.8 \%$ similarity (Table 2).

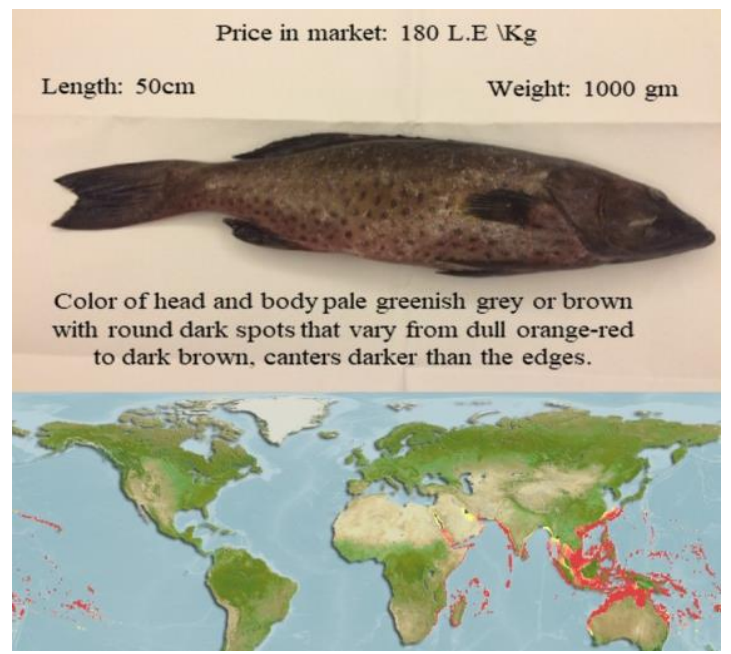

Fig 3. A photo of the Greasy Grouper (Hamour) Epinephelus tauvina (Above).The native distribution map for Epinephelus tauvina according to www.aquamaps.org, version of Aug. 2016 (Below)

For species 3 (Kahaya), the information retrieved for the Egyptian market confirmed its local common name as Kahaya, however, no significant search results were found to determine its taxonomical identity. The proposed name as Soldier fish was not correct, and neither was the proposed genus. The DNA barcoding analysis based on NCBI-BLAST matched it to $96 \%$ similarity of spiny squirrelfish, Sargocentron spiniferum of the same proposed family (Table 2). The fish is distributed through the Indo-Pacific to the Red Sea 
and East Africa to the Hawaiian and Ducie islands, north to southern Japan, south to Australia throughout Micronesia (Fig 4). The GenBank accession number for the sequences for samples is MW872754, MW872755 and MW872756 Scarus collana, Epinephelus tauvina and Sargocentron spiniferum respectively. (Table 2).

Table 2. Blast results of the three samples

\begin{tabular}{|c|c|c|c|}
\hline Sample & $\begin{array}{c}\text { Pairwise } \\
\%\end{array}$ & Organism & $\begin{array}{c}\text { Accession } \\
\text { number }\end{array}$ \\
\hline Species_1 & $99.2 \%$ & Scarus collana & MW872754 \\
\hline Species_2 & $99.8 \%$ & $\begin{array}{c}\text { Epinephelus } \\
\text { tauvina }\end{array}$ & MW872755 \\
\hline Species_2 & $96 \%$ & $\begin{array}{c}\text { Sargocentron } \\
\text { spiniferum }\end{array}$ & MW872756 \\
\hline
\end{tabular}

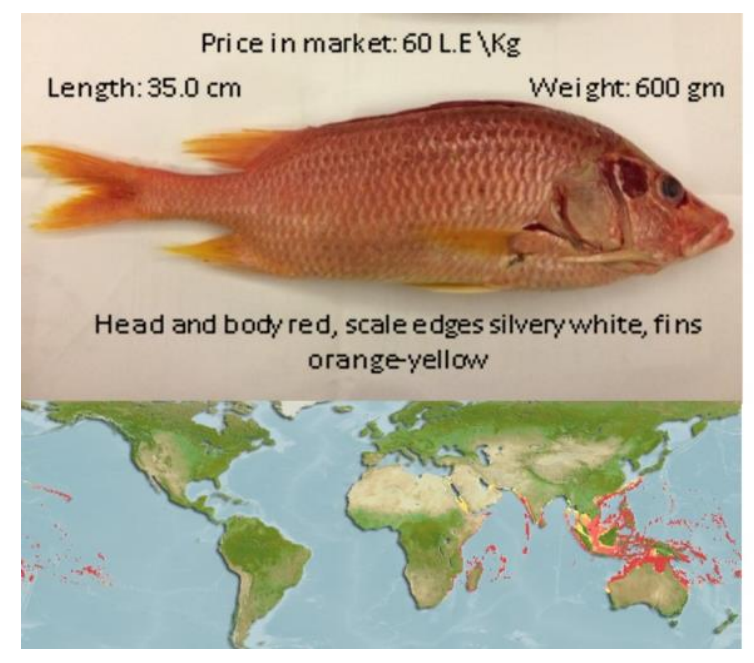

Fig 4. A photo of theSpiny squirrelfish (kahaya) Sargocentronspiniferum (Above). The native distribution map for Spiny squirrelfish according to www.aquamaps.org, version of Aug. 2016 (Below

We applied phylogenetic analysis on the currently studied species comparing each sequenced species with its closest related five accessions from the database and studying the relationships between those three economical fish. For parrotfish. The sample was clustered correctly with bootstrap value 1.00 . In contrast, species Nagil and Kahaya were clustered with bootstrap values of 0.95 and 0.76 , respectively, as shown in (Fig 5).

The above results indicate that Hamour and Nagil are members of the same family. Some of their species are very common in morphology, and most fish sellers may mislabel them in name tags on the market. Clustering analysis results based on Maximum likelihood of the barcoded samples were performed using COI sequences and GenBank similar accessions. Indicated that sample no.1 parrotfish was Scarus collana so there are no mislabel was found. Bottero and Dalmasso (2011) confirmed that although morphological characteristics are the first and most noticeable line for fish identification, accurate fish species recognition has become more vital for identification and resistance to market mislabeling.

On the other hand, the diagnostic characteristics are missing, customers are unable to define fish species. Alternative tools are required for food surveillance in these cases. For this reason, DNA-based methodologies are beneficial because DNA can be obtained successfully from finfish, fish tissue, and even from highly processed food (Teletchea et al 2005). The results of multiple phylogenetic trees confirmed that samples no. 2 and 3 were found related to Hamour fish (Epinephelus tauvina) and spiny fish (Sargocentron spiniferum). These results cleared that mislabeling was distributed mistakenly under other names, namely Nagil fish and Soldier fish. Hamour and Spiny fish did not match the expected genus and common Arabic name. Therefore, it is strongly suggested that the COI barcode be used to identify fish in the Egyptian market as a highresolution tool for fish species identification. Finally, we recommend that the Egyptian state agencies monitor the fish markets, especially the red sea fish markets, and eliminate the lack of awareness of these species and tighter controls on product substitution. 


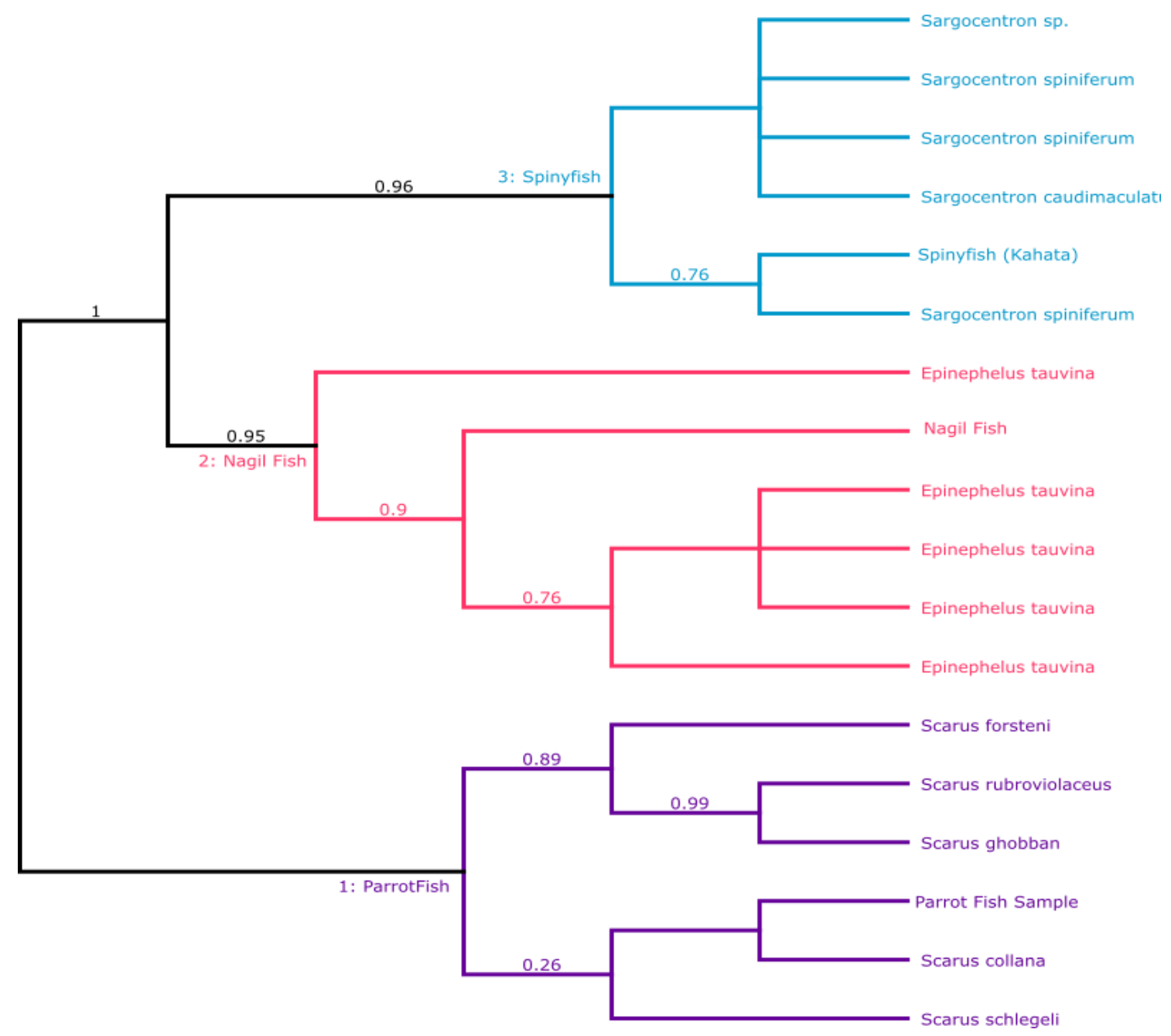

Fig 5. Maximum likelihood phylogenetic tree based on COI sequences, including the three studied species along with the top closest accessions retrieved with NCBI-BLAST analysis

\section{Conclusion}

We have applied the DNA barcoding technique to some Egyptian markets of marine fish from the red sea classified according to the fish market as Baghbaghan, Nagil and Kahaya compared the sampled species using COI sequences of evolution and estimation of the genetic distance. According to the fish market labeling, the results showed that Baghbaghan has been correctly identified, while Nagil and Kahaya are mistakenly distributed under other names. The new sequences were recorded in the Barcode database and GenBank database (http://www.ncbi.nlm. nih.gov/ Blast) to ensure correct identification of this species in the future. Future studies should be carried out to include more species with significant interest in the Egyptian fish market.

\section{Acknowledgments}

The authors are grateful to Dr. Samah Rizk for her critical review of the manuscript, and the team in applied genomics and biodiversity Laboratory, Department of Genetics, Faculty 


\section{from The Egyptian Market}

of Agriculture, Ain shams University, Cairo, Egypt, to support the technical part of the current work, the internal laboratory funds financially supported the current work.

\section{References}

Ahmed MI, Sabrah MM, Heneish RA, El-Alwany M (2016) DNA barcoding uncovers cryptic diversity in goat fishes (Family: Mullidae) across the Egyptian coastal waters. PJBS 19, 65-70.

Bottero MT, Dalmasso A (2011) Animal species identification in food products: Evolution of biomolecular methods. Vet J 190, 34-38.

Ebach MC, Carvalho MR (2010) Anti-Intellectualism in the DNA Barcoding Enterprise. Zoologica (Curitiba) 27, 165-178.

Galal-Khallaf A, Ardura A, Mohammed-Geba K, Borrell YJ, Garcia-Vazquez E (2014) DNA barcoding reveals a high level of mislabeling in Egyptian fish fillets. Food Control 46, 441445.

Hebert PD, Gregory TR (2005) The promise of DNA barcoding for taxonomy. Syst 54, 852859.

Hebert PD, Ratnasingham S, De Waard JR (2003) Barcoding animal life: cytochrome c oxidase subunit 1 divergences among closely related species. Proc Royal Soc Biol Sci 270, 96-99.
Ivanova NV, Zemlak TS, Hanner R H, Hebert PD (2007) Universal primer cocktails for fish DNA barcoding. Mol Ecol Notes 7, 544-548.

Rasmussen RS, Morrissey MT (2008) DNA based methods for the identification of commercial fish and seafood species. COMPR REV FOOD SCI F 7, 280-295.

Strauss RE, Bond CE(1990) Taxonomic methods: Morphology. In: Schreck, CB, Moyle, PB (Eds). Methods for Fish Biology. American Fisheries Society, Bethesda, pp. 109-140.

Teletchea F, Maudet C, Hänni C (2005). Food and forensic molecular identification: update and challenges. Trends Biotechnol 23, 359366.

Tesfamichael D, Pauly D (2016). The Red Sea ecosystem and fisheries Vol. 7, Springer New York, USA.

Ward RD, Zemlak TS, Innes BH, Last PR, Hebert PD (2005). DNA barcoding Australia's fish species. Philos Trans R Soc Lond B Biol Sci 360, 1847-1857.

Younas T (2016) An efficient method of DNA isolation from fish fin. PakJ Agri Sci 53, 843850 .

www.fishbase.org (accessed 21-3-2018)

http://www.barcoding.si.edu (accessed 18-82019)

www.aquamaps.org (accessed 21-3-2018) 